\title{
Influence of Game-Based Learning in Mathematics Education on Students' Affective Domain: A Systematic Review
}

\author{
Peter Vankúš
}

check for updates

Citation: Vankúš, P. Influence of

Game-Based Learning in

Mathematics Education on Students' Affective Domain: A Systematic

Review. Mathematics 2021, 9, 986.

https://doi.org/10.3390/math9090986

Academic Editor: Francisco

D. Fernández-Martín

Received: 28 March 2021

Accepted: 25 April 2021

Published: 28 April 2021

Publisher's Note: MDPI stays neutral with regard to jurisdictional claims in published maps and institutional affiliations.

Copyright: (C) 2021 by the author. Licensee MDPI, Basel, Switzerland. This article is an open access article distributed under the terms and conditions of the Creative Commons Attribution (CC BY) license (https:/ / creativecommons.org/licenses/by/ $4.0 /$ )
Faculty of Mathematics, Physics, and Informatics, Comenius University in Bratislava, 84248 Bratislava, Slovakia; peter.vankus@fmph.uniba.sk

\begin{abstract}
In modern education nowadays, the use of game-based learning as a teaching and learning method is popular in all school subjects, including mathematics. There are numerous studies dealing with the influences of this teaching method on the students' achievements. Modern teaching theories consider an important effect of education on the development of students' affective domain, connected with the subject and its teaching. In this work, the author studies journal articles that the use game-based learning in mathematics to assess its effects on the students, with the aim to analyze its impact on students' affective domain. To achieve this, a systematic review with the use of a PRISMA statement is applied. The data sources are 57 journal articles from the area of interest listed in the Web of Sciences and Scopus. The results indicate that $54 \%$ of the articles consider the affective domain in the measurement of the effects of game-based learning in mathematics education. These articles report mostly ( $84 \%$ ) the positive influences of game-based learning on students' motivation, engagement, attitudes, enjoyment, state of flow, etc. The rest of the articles show mixed results, with the authors' conclusions possibly affected by flaws in the research instruments, selection of study groups, and game design, therefore, stressing the importance of these elements in future research on this topic.
\end{abstract}

Keywords: game-based learning; affective domain; mathematics education; systematic review

\section{Introduction}

Based on the fast progress of sciences and technologies, continuous innovations of the content, methods, and goals of school mathematics education are needed. One of the promising methods to achieve the active participation of students in learning activities and their higher motivation is game-based learning [1,2].

Game-based learning encourages active learning and engagement by providing students with possibilities to place problem-solving within the context of play [3].

The idea of games as an educational tool is not a new one, it was originally devised by Hellenic philosophers, Plato and Aristotle. In more recent history, game-based education has been part of the educational theories of important figures in this scientific area, such as J. A. Comenius (1592-1670), J. H. Pestalozzi (1746-1827), F. W. Fröbel (1782-1852), H. Spencer (1820-1903), K. Groos (1861-1946), M. Montessori (1870-1952), J. Piaget (1896-1980), L. S. Vygotsky (1896-1934), and J. Dewey (1859-1952) [4].

The impetus for the vast integration of game-based learning nowadays is driven by other factors, including the inclusion of digital technologies in education. Digital games support learning by giving students an opportunity to develop knowledge and cognitive skills, to learn by problem-solving, and to experience situational learning [5,6].

With this huge increase in game-based learning applications come natural questions about their effects on students. Many studies and reviews of existing research in this area have been conducted, mostly focused on the effect of games on students' performance compared with that of traditional classroom instruction [7].

Randel et al. [8], in their review, compared the effect on student's performance of games with that of traditional teaching in 68 studies up to 1991. The results were mixed; 
the beneficial effects of games were mostly found when specific content was targeted. The review study of Hays [9], including 105 instructional gaming articles, also reported that the use of games in specific areas can provide effective learning, but the general conclusion was that there is no evidence that games are a preferred instructional method in all situations.

In the area of mathematics, educational games were identified as suitable to promote mathematic achievements in various domains, e.g., problem-solving and algebra skills [10], strategic and reasoning abilities [11], geometry skills [12], arithmetic [13,14], and critical thinking [15]. These studies are mostly focused on game-based learning's influences on mathematical achievements in the form of knowledge. But other important parts of mathematic education are affective factors such as students' motivation, beliefs, and attitudes towards mathematics and its teaching, as these factors can have a big impact on students' mathematical skills and their future mathematic learning [16-18]. Therefore, the question arises of how and to what extent game-based learning in mathematics education influences students' affectional dimension.

This question has already been discussed in some studies and reviews. The research of Garris et al. [19] found out that games could improve the engagement of students, advocating that games could influence outcomes including attitudes. These games were used in the setting of school education, but also in adult training. The study of Vogel et al. [20] reported positive effects of games vs. traditional teaching methods for both cognitive gains and attitude. However, the authors of the study considered the reliability to be low. The study of Ke and Grabowski [21] dealt with the effect of game-based learning on fifth-grade students' mathematics performance and attitudes. The results indicated that the integration of games positively influenced attitudes towards mathematics, mostly in cooperative structured groups. Based on a review of previous research studies, Vandercruysse [22] suggests that educational games positively affect students' attitudes, though just three journal articles support this suggestion.

The above-mentioned studies imply possible influences of game-based learning on students' affective factors connected with mathematics and its teaching process. However, these indications are fragmented and do not give a general overview of the influences of game-based learning on students' mathematics. Therefore, there is a need for a systematic review of the journal papers dealing with game-based learning in mathematics, focusing on the present state of research on the influences of game-based learning upon student's affective domain.

Based on this need, in the current paper, the following questions are investigated:

Q1: To what extent do the research studies dealing with the effects of game-based learning in the field of mathematics education address the influence of this teaching method on students' affective domain, connected with mathematics and its teaching?

Q2: Which journals have published scientific articles in this field?

Q3: What have been the influences of game-based learning on students' affective domain?

Q4: What research instruments were used to measure the influences of game-based learning on the affective factors?

To present answers to the research questions, the paper has the following structure. The next chapter details the materials and methods used for this systematic review. The third chapter states the result of the systematic review concerning the research questions. The last chapter discusses the results, comparing them with the outcomes of other studies, summarizes the limitations of the study, and proposes ideas for future research on this topic.

\section{Materials and Methods}

To answer the research questions, a systematic review was selected as the most appropriate research method, as it was developed for identifying and synthesizing research evidence by taking a systematic approach, following transparent and rigorous processes [23]. As the protocol for this systematic review, the author used the Preferred Reporting Items for Systematic Reviews and Meta-Analysis (PRISMA) framework [24]. The reason behind the choice of PRISMA over other existing protocols was its comprehensiveness, its use in 
several disciplines worldwide beyond the medical field for which it was originally developed, and its capability to increase consistency across reviews. The PRISMA checklist used in this paper reflects the fact that it is a systematic review, not a meta-analysis. Therefore, checklist items 12-16 and 19-23 were not included [24] (p. 3). This is in accordance with the recommendations on PRISMA applications for systematic review studies [25].

The eligibility criteria for the papers included in this systematic review are specified in Table 1.

Table 1. The criteria for eligibility.

\begin{tabular}{|c|c|c|}
\hline Criterion & Inclusion & Exclusion \\
\hline Document type & $\begin{array}{l}\text { Published journal article (both } \\
\text { empirical and review) }\end{array}$ & $\begin{array}{c}\text { Book, book chapter, } \\
\text { conference presentation, } \\
\text { or other type of } \\
\text { non-peer-reviewed or } \\
\text { unpublished publication }\end{array}$ \\
\hline Language & English & Articles not written in English \\
\hline Accessibility & $\begin{array}{c}\text { Open-access version of } \\
\text { the article }\end{array}$ & $\begin{array}{l}\text { Source with no open-access } \\
\text { version available }\end{array}$ \\
\hline
\end{tabular}

According to the criteria, only published versions of journal articles are selected. This means that books, chapters in books, conference proceedings, etc., are excluded. This particular criterion is based on the higher scientific validity of peer-reviewed published journal articles when compared with other types of reports. For the journal articles, both empirical data articles and review articles are included, to cover the biggest possible range of data. The second selection criterion is the language; journal articles are accepted that are written in English. This is to avoid any confusion due to problems with translation and misunderstanding. The third inclusion criterion is that the open-access version of the article is used, to enable the extraction of all relevant data during the data collection process. The timeframe of selected articles is not limited, again, to achieve the biggest collection of relevant sources.

As information sources for this systematic review study, the author selected two major databases, namely Scopus and Web of Science. This selection was based on the broad range of the themes and journals covered in these databases, and their high scientific recognition. The items in these databases are systematically structured and search algorithms are provided that offer the possibility of covering all three eligibility criteria.

The search of the selected databases was implemented on 16 March 2021. The search terms were 'game-based learning' or 'games' combined with a Boolean operator AND with the terms 'mathematics' or 'math'. The exact search strings and limits used are listed in Table 2.

Table 2. The search strings and limits used for the electronic search process.

\begin{tabular}{|c|c|}
\hline Database & Search String and Limits \\
\hline Scopus & $\begin{array}{l}\text { TITLE (("game" OR “game-based”) AND (“mathematics” OR } \\
\text { “math")) AND (LIMIT-TO (PUBSTAGE, “final”)) AND (LIMIT-TO } \\
(\text { OA, “all”)) AND (LIMIT-TO (DOCTYPE, “ar")) AND (LIMIT-TO } \\
\text { (LANGUAGE, “English”)) AND (LIMIT-TO (SRCTYPE, “j”)) }\end{array}$ \\
\hline Web of Science & $\begin{array}{c}\text { TI = (("game" OR "game-based") AND ("mathematics" OR "math"))) } \\
\text { AND LANGUAGE: (English) AND DOCUMENT TYPES: (Article) } \\
\text { Refined by: Open Access: (OPEN ACCESS) } \\
\text { Timespan: All years. Indexes: SCI-EXPANDED, SSCI, A\&HCI, } \\
\text { CPCI-S, CPCI-SSH, BKCI-S, BKCI-SSH, ESCI, CCR-EXPANDED, IC. }\end{array}$ \\
\hline
\end{tabular}




\section{Results}

The initial search highlighted 68 document results in the Scopus database and 37 results in the Web of Science database. The search results including the abstracts were exported for further screening in MS Excel. The next stage was the identification of duplicates, which led the author to find 20 duplicate records; those were excluded. The remaining records' abstracts were carefully studied to judge their relevance. A total of 27 articles were excluded as they did not focus on the effects of game-based learning in mathematics education. The remaining 58 papers were retrieved in the full text form. They were screened to further inspect their relevance. During this process, one paper was excluded since it was only partially written in English. This process left 57 articles; those are included in the qualitative synthesis described in the next part of the paper. A graphical representation of the flow of citations reviewed during the systematic review process is presented in Figure 1.

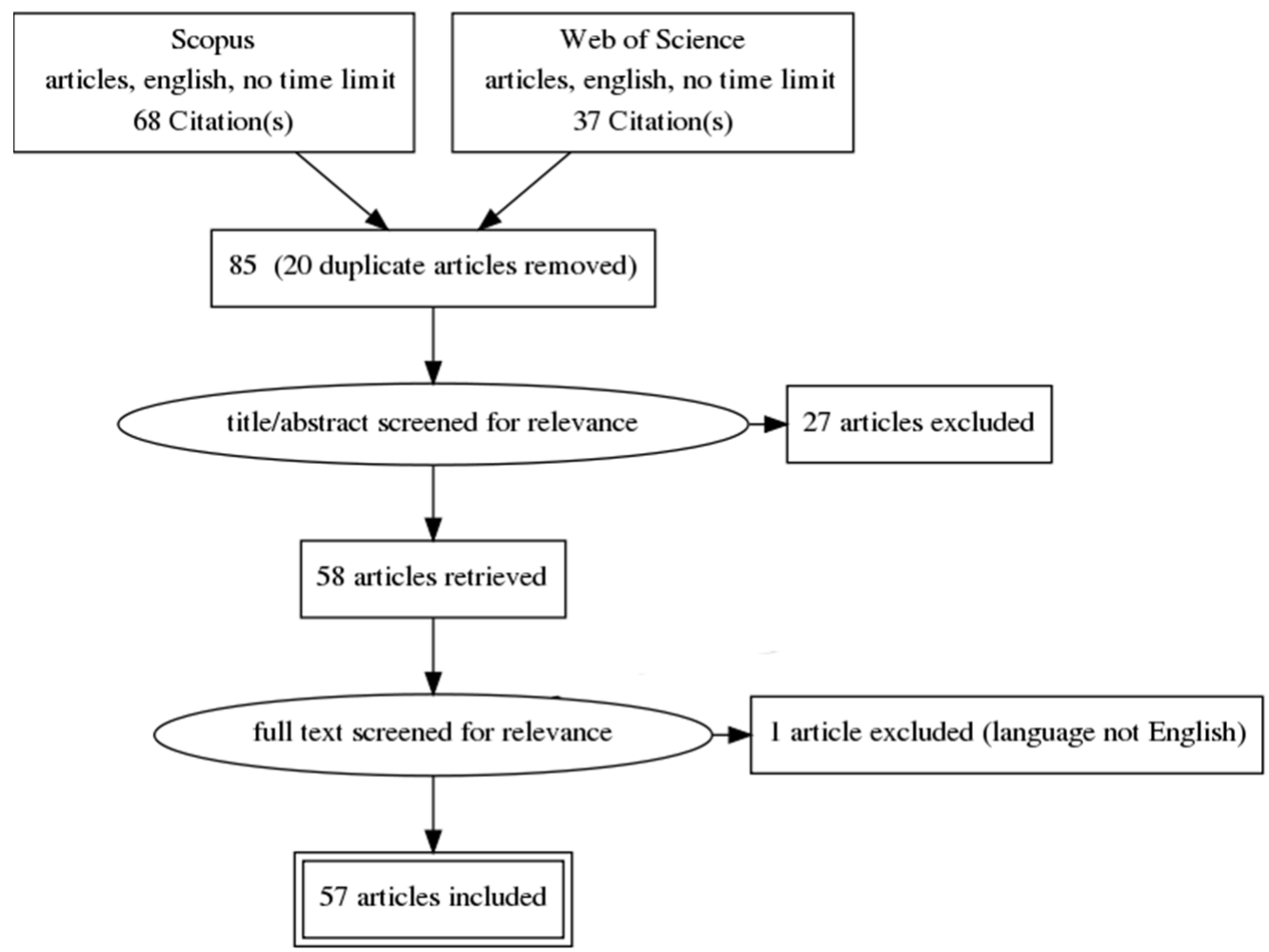

Figure 1. Systematic review flow diagram. Generated by PRISMA Flow Diagram Generator. Available online: http:/ / prisma.thetacollaborative.ca / (accessed on 20 March 2021).

The 57 included articles were thoroughly studied to identify the results connected with the research questions of this paper. For this analysis, the software ATLAS.ti 9 was used, mainly because it enabled the analyst to solve a range of methodological challenges, such as working with large datasets and supporting deeper levels of analysis than are possible by hand [26]. During analysis, the author found that 26 articles [27-52] did not discuss the direct effects of game-based learning on the affective domain. So, to answer research questions Q2-Q4, the 31 remaining studies are investigated [6,53-82]. Table 3 summarizes the main characteristics of these game-based learning studies, with detailed information concerning the research questions. 
Table 3. Study characteristics.

\begin{tabular}{|c|c|c|c|c|}
\hline Ref. & Journal & $\begin{array}{c}\text { Influence on MRAF }{ }^{1} \\
\text { [Posi- } \\
\text { tive/Negative/Mixed] }\end{array}$ & $\begin{array}{l}\text { Measured Aspects of } \\
\text { Affective Domain }\end{array}$ & $\begin{array}{l}\text { Instruments to } \\
\text { Measure MRAF }^{1}\end{array}$ \\
\hline$[53]$ & Aust. J. Teach. Educ. & positive & $\begin{array}{l}\text { motivation, engagement, } \\
\text { state of flow, self-efficacy }\end{array}$ & $\begin{array}{l}\text { questionnaire, } \\
\text { video data }\end{array}$ \\
\hline$[54]$ & Aust. J. Teach. Educ. & positive & motivation, attitudes & interview \\
\hline [55] & Br J Educ Technol & positive & motivation, attitudes & questionnaire \\
\hline$[56]$ & Br. J. Educ. Technol. & positive & motivation, engagement & observations \\
\hline [57] & Education Tech. Research Dev. & mixed & motivation & questionnaire \\
\hline [58] & EJEL & positive & attitudes & questionnaire \\
\hline [59] & Eurasia J. Math. Sci. Technol. Educ. & mixed & attitudes, anxiety & questionnaire \\
\hline$[60]$ & Eurasia J. Math. Sci. Technol. Educ. & positive & motivation & unspecified \\
\hline$[61]$ & IEEE Access & positive & $\begin{array}{c}\text { motivation, engagement, } \\
\text { attitudes }\end{array}$ & questionnaire \\
\hline$[62]$ & $\mathrm{iJOE}$ & positive & motivation & literature review \\
\hline [63] & IJSG & positive & motivation & video data \\
\hline$[64]$ & Informatics Educ. & positive & $\begin{array}{c}\text { motivation, engagement, } \\
\text { enjoyment }\end{array}$ & $\begin{array}{l}\text { questionnaire, } \\
\text { interview }\end{array}$ \\
\hline$[65]$ & Int. J. Artif. Intell. Educ. & positive & motivation & unspecified \\
\hline$[66]$ & Int. J. Multimedia Ubiquitous Eng. & positive & motivation & literature review \\
\hline [67] & Int. J. Technol. Enhanc. Learn. & positive & state of flow & questionnaire \\
\hline$[68]$ & J Educ Psychol & positive & $\begin{array}{c}\text { motivation, engagement, } \\
\text { attitudes }\end{array}$ & questionnaire \\
\hline [69] & J Educ Techno Soc & positive & self-efficacy, state of flow & questionnaire \\
\hline$[70]$ & J Math Didakt & positive & motivation, engagement & video data \\
\hline$[71]$ & J. Comput. Educ. & positive & $\begin{array}{c}\text { motivation, self-efficacy, } \\
\text { attention }\end{array}$ & questionnaire \\
\hline [72] & J. Educ. E-Learn. Res. & mixed & attitudes & questionnaire \\
\hline [73] & J. Educ. Techno. Soc. & positive & $\begin{array}{c}\text { motivation, enjoyment, } \\
\text { engagement }\end{array}$ & $\begin{array}{c}\text { questionnaire, active } \\
\text { participation }\end{array}$ \\
\hline$[74]$ & J. Inf. Organ. Sci. & positive & motivation, attitudes & literature review \\
\hline [75] & J. Math. Educ. & positive & attitudes & questionnaire \\
\hline [6] & Math. Ed. Res. J. & mixed & attitudes & $\begin{array}{l}\text { questionnaire, } \\
\text { interview, game data }\end{array}$ \\
\hline$[76]$ & MJLI & mixed & motivation & video data \\
\hline [77] & MJLI & positive & motivation & unspecified \\
\hline [78] & Rev. Colomb. Comput. & positive & motivation & questionnaire \\
\hline [79] & Simul. Gaming & positive & motivation & active participation \\
\hline$[80]$ & Technol. Knowl. Learn. & positive & enjoyment & game data \\
\hline [81] & Technologies & positive & engagement, enjoyment & questionnaire \\
\hline [82] & Univers. J. Educ. Res. & positive & motivation & questionnaire \\
\hline
\end{tabular}

${ }^{1}$ Mathematics-related affective factors.

\subsection{Extent of the Studies Considering the Affective Domain}

As mentioned previously, of the 57 studies included in this systematic review, 31 (54\%) addressed the affective domain in game-based learning in mathematics education, while $26(46 \%)$ did not study the influences of game-based learning on the affective domain. The papers dealing with the affective domain were mostly from the last decade, and their number has slowly increasing trend, as can be seen in Figure 2.

\subsection{Journals Publishing Studies Considering the Affective Domain}

The 31 identified studies with research directly targeting the affective domain were published in scientific journals. Four journals $(15 \%)$ contained two studies, while the remaining 23 journals ( $85 \%$ ) included a single study. The scientific orientation of these journals was mostly Education and Educational Research, followed by Computer Science Interdisciplinary Applications, Psychology and Educational Sciences, and other similar scientific disciplines. 


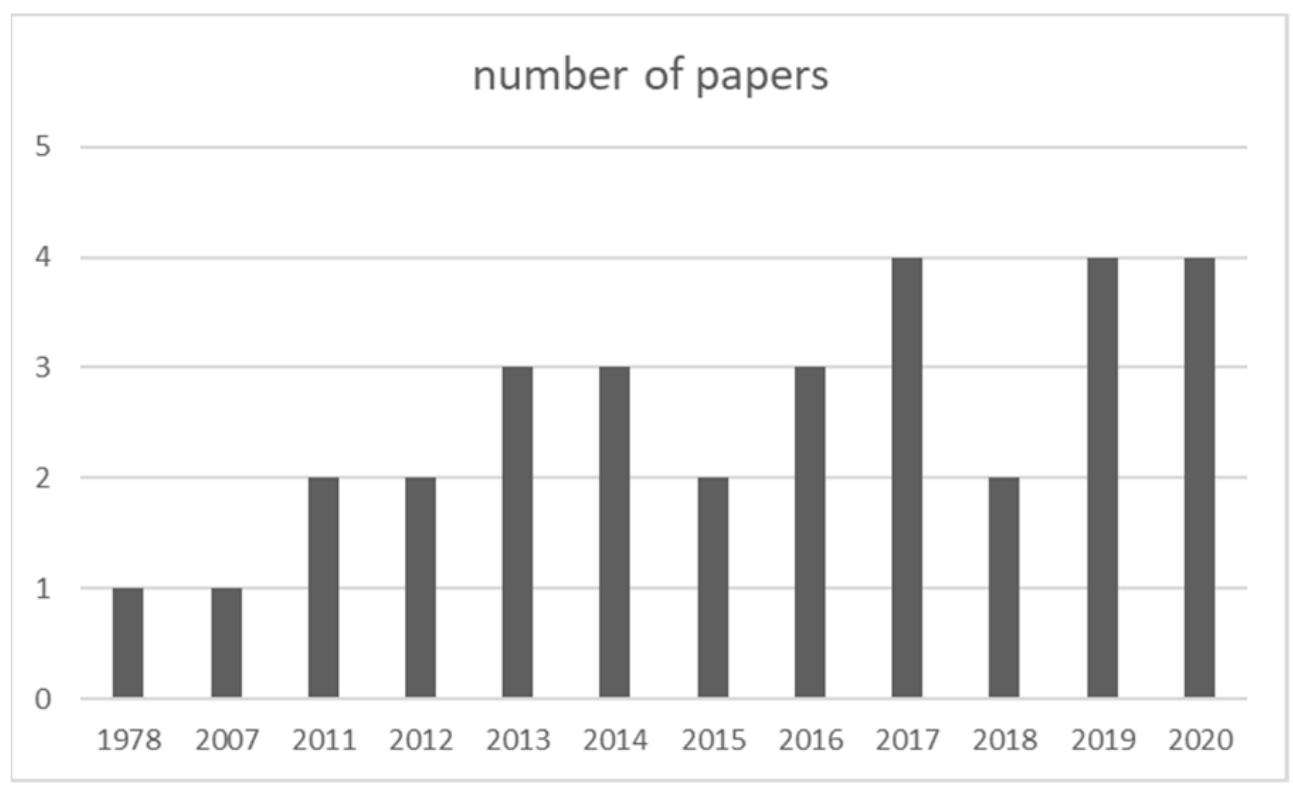

Figure 2. Publishing years of the source studies concerning the affective domain.

\subsection{Influences of Game-Based Learning on the Affective Domain}

The majority (26, i.e., $84 \%$ ) of the journal articles dealing with the affective domain reported positive influences of game-based learning on students. These positive results related to the students' motivation (20 studies), engagement (eight studies), attitudes (seven studies), enjoyment (four studies), state of flow (three studies), and attention (one study). As for the number per study, one study reported four of the above-mentioned affective domain elements with positive results due to game-based learning, five studies reported three elements, seven studies considered two elements, and the remaining 13 studies focused on just one element of the affective domain.

The remaining five (16\%) journal articles stated mixed results of game-based learning in mathematics education on students' affective domain. These results related to attitudes (three studies), motivation (two studies), and anxiety (one study). Of these studies with mixed results, one study addressed two elements of the affective domain and four studies just one element.

\subsection{Instruments Used to Measure the Influences of Game-Based Learning on the Affective Domain}

The most widely used research tool to study the influences of game-based learning on students' affective domain in mathematics education was a questionnaire, used in 18 studies (58\%). The next most often used instrument was the analysis of video data (four studies), followed by an interview with the game participants (three studies), analysis of the data and metadata from the game (two studies), analysis of students' participation during game-based activities (two studies), and observation of students learning processes (one study). Three studies included literature reviews and three studies did not specify their research instruments.

Considering the number of instruments per study, one study used three of the abovementioned instruments, three studies use two instruments, and the remaining studies used just one instrument or did not specify the instruments used.

\section{Discussion}

This systematic review concerns the influences of game-based learning on the affective domain, as studied in $54 \%$ of the journal articles in the area of game-based learning in mathematics education. These articles are mostly from the last decade and there is a slowly increasing trend of their number per year. The articles are published in various scientific journals with a broad scientific scope. This underlines that researchers in this 
field understand the importance of the affective domain for effective teaching, as many include this important dimension in their studies. There is a trend of increasing research focused on the affective domain [16-18].

Considering the research instruments, the author found that the studies included mainly questionnaires $(58 \%)$, interviews $(12 \%)$, and analysis of video data $(10 \%)$, or a combination of these instruments, which are standard in the assessment of the affective domain. This finding follows a general trend in research on this topic [83].

One very promising result of this review is the fact that the majority $(84 \%)$ of the studied journal articles report positive effects of game-based learning on students' affective domain. These results mostly include increases in motivation and engagement, and improvements in students' attitudes related to mathematical content and its teaching. Although some of the articles report mixed results, none report a negative impact. The positive influences of game-based learning on the affective domain are in accordance with previous research in this area [19-22].

Those with mixed results note that playing the selected game did not have a discernible effect on students' motivation to learn math [57]. The authors conclude that this is because they incorporated into the game features that they believed would be entertaining, but that proved not to be the case for students. Alternatively, the questionnaire was not appropriately framed to allow the researchers to detect any effects on motivation. Another study [59] reports that in terms of learning anxiety, significant differences between students in the high-score and low-score groups may be a result of family factors, as most of the students in the high-score group were very familiar with computer operations, compared with students in the low-score group who had limited experience using computers. The other study with mixed results [72] shows that the use of mathematical games in math courses does not change students' attitudes towards mathematics courses in terms of the content that they are learning. However, in contrast, it was observed that students were much more active and had fun when learning; in addition, informal interviews with students showed that students had positive feelings and thoughts about their mathematics lessons. The authors conclude that this conflict in the results occurs since primary school students who are still in the concrete process period may not be able to fully internalize the scale items in the questionnaire used in the research. The article [76] states, as a reason for the mixed results, different play preferences and motivation, based on the content of the game and to what extent it motivates students and matches their preferences.

The limitations of this study concern the focus on journal articles, thus omitting other sources as books, book chapters, and conference papers. Moreover, this study focuses only on articles written in English. The author was also not able to include articles that were not open-access, which again limits the sample. However, the included databases Scopus and Web of Science are highly representative, and English is used in most of the scientific journals, therefore, these limitations should not influence the overall comprehensive nature of the study.

In conclusion, this systematic review indicates mostly positive influences of gamebased learning on students' affective domain ( $84 \%$ of studies). Studies with mixed results, according to their authors, are mostly influenced by inappropriate research instruments, mistakes with the game design, or special conditions within the study groups. Based on this, the author can conclude that if those limiting factors are not present, then it is likely that positive influences of game-based learning will be recorded on students' affective domain. Therefore, proper research instruments, selection of study groups, and game design are recommended for future research on the topic of the influences of game-based learning.

Funding: This research was funded by the Ministry of Education, Science, Research and Sport of the Slovak Republic; grant number KEGA 007UK-4/2020. 
Conflicts of Interest: The author declares no conflict of interest. The funders had no role in the design of the study; in the collection, analyses, or interpretation of data; in the writing of the manuscript, or in the decision to publish the results.

\section{References}

1. Clark, D.B.; Tanner-Smith, E.E.; Killingsworth, S.S. Digital games, design, and learning: A systematic review and meta-analysis. Rev. Educ. Res. 2016, 86, 79-122. [CrossRef]

2. Noroozi, O.; Dehghanzadeh, H.; Talaee, E. A systematic review on the impacts of game-based learning on argumentation skills. Entertain. Comput. 2020, 35. [CrossRef]

3. Ebner, M.; Holzinger, A. Successful implementation of user-centered game based learning in higher education: An example from civil engineering. Comput. Educ. 2007, 49, 873-890. [CrossRef]

4. Vankúš, P. History and present of didactical games as a method of mathematics teaching. Acta Didact. Univ. Comen. Math. 2005, 5, 53-68.

5. Holzinger, A.; Nischelwitzer, A.; Meisenberger, M. Lifelong-Learning support by m-learning: Example scenarios. Elearn $2005,11$. [CrossRef]

6. Divjak, B.; Tomic, D. The impact of Game-based learning on the achievement of learning goals and motivation for learning mathematics-literature review. J. Inf. Organ. Sci. 2011, 35, 15-30.

7. Ke, F.A. Qualitative Meta-Analysis of Computer Games as Learning Tools. In Handbook of Research on Effective Electronic Gaming in Education; Ferdig, R.E., Ed.; IGI Global: Hershey, PA, USA, 2009; pp. 1-32. [CrossRef]

8. Randel, J.M.; Morris, B.A.; Wetzel, C.D.; Whitehill, B.V. The Effectiveness of Games for Educational Purposes: A Review of Recent Research. Simul. Gaming. 1992, 23, 261-276. [CrossRef]

9. Hays, R.T. The Effectiveness of Instructional Games: A Literature Review and Discussion; Naval Air Warfare Center: Orlando, FL, USA, 2005.

10. Abramovich, S. Topic in Mathematics for Elementary Teachers: A Technology-Enhanced Experiential Approach; Information Age Publishing, Inc.: Charlotte, NC, USA, 2010.

11. Bottino, R.M.; Ferlino, L.; Ott, M.; Tavella, M. Developing strategic and reasoning abilities with computer games at primary school level. Comput. Educ. 2007, 49, 1272-1286. [CrossRef]

12. Yang, J.C.; Chen, S.Y. Effects of gender differences and spatial abilities within a digital pentominoes game. Comput. Educ. 2010, 55, 1220-1233. [CrossRef]

13. Moreno, R.; Durán, R. Do Multiple Representations Need Explanations? The Role of Verbal Guidance and Individual Differences in Multimedia Mathematics Learning. J. Educ. Psychol. 2004, 96, 492-503. [CrossRef]

14. Tokac, U.; Novak, E.; Thompson, C.G. Effects of game-based learning on students' mathematics achievement: A meta-analysis. J. Comput. Assist. Learn. 2019, 35, 407-420. [CrossRef]

15. Cicchino, M.I. Using Game-Based Learning to Foster Critical Thinking in Student Discourse. Interdiscip. J. Probl. Based Learn. 2015, 9. [CrossRef]

16. Papanastasiou, C. Effects of attitudes and beliefs on mathematics achievement. Stud. Educ. Eval. 2000, 26, 27-42. [CrossRef]

17. Kloosterman, P. Beliefs About Mathematics and Mathematics Learning in the Secondary School: Measurement and Implications for Motivation. In Beliefs: A Hidden Variable in Mathematics Education? Mathematics Education Library; Leder, G.C., Pehkonen, E., Törner, G., Eds.; Springer: Dordrecht, The Netherlands, 2002; Volume 31. [CrossRef]

18. Di Martino, P.; Zan, R. Attitude towards mathematics: A bridge between beliefs and emotions. ZDM 2011, 43, 471-482. [CrossRef]

19. Garris, R.; Ahlers, R.; Driskell, J.E. Games, Motivation, and Learning: A Research and Practice Model. Simul. Gaming 2002, 33, 441-467. [CrossRef]

20. Vogel, J.F.; Vogel, D.S.; Cannon-Bowers, J.; Bowers, C.A.; Muse, K.; Wright, M. Computer gaming and interactive simulations for learning: A meta-analysis. J. Educ. Comput. Res. 2006, 34, 229-243. [CrossRef]

21. Ke, F.; Grabowski, B. Gameplaying for maths learning: Cooperative or not? Br. J. Educ. Technol. 2007, 38, 249-259. [CrossRef]

22. Vandercruysse, S.; Vandewaetere, M.; Clarebout, G. Game-Based Learning: A Review on the Effectiveness of Educational Games. In Handbook of Research on Serious Games as Educational, Business and Research Tools; Cruz-Cunha, M.M., Ed.; IGI Global: Hershey, PA, USA, 2012; pp. 628-647. [CrossRef]

23. Victor, L. Systematic reviewing. Soc. Res. Update 2008, 54, 1-4.

24. Liberati, A.; Altman, D.G.; Tetzlaff, J.; Mulrow, C.; Gotzsche, P.C.; Ioannidis, J.P.A.; Clarke, M.; Devereaux, P.J.; Kleijnen, J.; Moher, D. The PRISMA statement for reporting systematic reviews and meta-analyses of studies that evaluate health care interventions: Explanation and elaboration. J. Clin. Epidemiol. 2009, 62, e1-e34. [CrossRef]

25. Pahlevan-Sharif, S.; Mura, P.; Wijesinghe, S.N.R. A systematic review of systematic reviews in tourism. J. Hosp. Tour. Manag. 2019, 39, 158-165. [CrossRef]

26. Paulus, T.M.; Lester, J.N. ATLAS.ti for conversation and discourse analysis studies. Int. J. Soc. Res. 2016, 19, 405-428. [CrossRef]

27. Aljojo, N. The Design and Implementation of a Mathematics Game-Base Learning Application for Primary Students. Int. J. Interact. Mob. Technol. 2018, 12, 142-152. [CrossRef]

28. Broley, L.; Buteau, C.; Muller, E. E-Brock Bugs@: An Epistemic Mathematics Computer Game. J. Humanist. Math. 2015 , 5, 3-25. [CrossRef] 
29. Broley, L.; Buteau, C.; Muller, E. Struggles and Growth in Mathematics Education: Reflections by Three Generations of Mathematicians on The Creation of the Computer Game E-Brock Bugs. J. Humanist. Math. 2017, 7, 62-86. [CrossRef]

30. Carr, J.M. Does Math Achievement $h$ APP en when iPads and Game-Based Learning Are Incorporated into Fifth-Grade Mathematics Instruction? JITE Res. 2012, 11, 269-286. [CrossRef]

31. Drummond, A.; Sauer, J.D. Video-Games Do Not Negatively Impact Adolescent Academic Performance in Science, Mathematics or Reading. PLoS ONE 2014, 9, e87943. [CrossRef]

32. Gris, G.; Alves, H.W.; Assis, G.J.A.; de Souza, S.R. The Use of Adapted Games for Assessment of Mathematics and Monetary Skills. Trends Psychol. Temas Em Psicol. 2017, 25, 1153-1166. [CrossRef]

33. Gyöngyösi-Wiersum, E.; Czapné, Z.; Makrides, G. Situation games to ease transition betweenabstract and real life mathematics forprimary school student teachers. Ann. Math. Inform. 2019. [CrossRef]

34. Harikrishnan, H.; Abd Halim, N.; Harun, J.; Arjunan, S. Exploring the Digital Game-Based Elements in Mathematics Education: A Meta-Analysis Review. Univers. J. Educ. Res. 2019, 7, 106-116. [CrossRef]

35. Hwa, S.P. Pedagogical Change in Mathematics Learning: Harnessing the Power of Digital Game-Based Learning. J. Educ. Technol. Soc. 2018, 21, 259-276.

36. Jensen, E.; Hanghøj, T. What's the math in Minecraft? A Design-Based Study of Students' Perspectives and Mathematical Experiences Across game and School Domains. Electron. J. Elearn. 2020, 18, 261-274. [CrossRef]

37. Juric, P.; Brkic Bakaric, M.; Matetic, M. Design and Implementation of Anonymized Social Network-based Mobile Game System for Learning Mathematics. Int. J. Emerg. Technol. Learn. 2018, 13, 83-98. [CrossRef]

38. Kermani, H. Computer mathematics games and conditions for enhance young children's learning of number sense. Malays. J. Learn. Instr. 2017, 14, 23-57. [CrossRef]

39. McLaren, B.; Adams, D.; Mayer, R.; Forlizzi, J. A Computer-Based Game that Promotes Mathematics Learning More than a Conventional Approach. Int. J. Game Based Learn. 2017, 7, 36-56. [CrossRef]

40. Moyer-Packenham, P.S.; Lommatsch, C.W.; Litster, K.; Ashby, J.; Bullock, E.K.; Roxburgh, E.K.; Shumway, J.F.; Speed, E.; Covington, B.; Hartmann, C.; et al. How design features in digital math games support learning and mathematics connections. Comput. Hum. Behav. 2019, 91, 316-332. [CrossRef]

41. Pemu, N.; Zulkardi, Z. Building counting by traditional game: Mathematics Program for Young Children. J. Math. Educ. 2011, 2. [CrossRef]

42. Nkopodi, N.; Mosimege, M. Incorporating the indigenous game of morabaraba in the learning of mathematics. S. Afr. J. Educ. 2009, 29, 377-392. [CrossRef]

43. Nsubuga, E.S.; Cajigas, J.B.; Rombaoa, J.A.L.; Garcia, J.M.M.; Cruz, D.P.; Olfato, D.C.G.; Ca, C.M.E. Matherpiece: An Introduction to Math E-Learning PC Game Application for Grade 1 Pupils. Comput. Hum. Behav. 2019, 8. [CrossRef]

44. Nugroho, E.W.; Chandrawati, T.B. Detection Hand Motion on Virtual Reality Mathematics Game with Accelerometer and Flex Sensors. Detect. Hand Motion Virtual Real. Math. Game Accelerometer Sens. 2018, 16, 2287-2292. [CrossRef]

45. Pope, H.; Mangram, C. Wuzzit Trouble: The Influence of a Digital Math Game on Student Number Sense. Int. J. Serious Games 2015, 2. [CrossRef]

46. Sukstrienwong, A. Animo Math: The Role-Playing Game in Mathematical Learning for Children. Tem J. 2018, 7, 147-154.

47. Ting, F.; Lam, W.; Shroff, R. Active Learning via Problem-Based Collaborative Games in a Large Mathematics University Course in Hong Kong. Educ. Sci. 2019, 9, 172. [CrossRef]

48. Turgut, S.; Temur, Ö. The Effect of Game-Assisted Mathematics Education on Academic Achievement in Turkey: A Meta-Analysis Study. Int. Electron. J. Elem. Educ. 2017, 10, 195-206. [CrossRef]

49. Widyasari, W.; Sutopo, H.; Agustian, M. QR Code-based Learning Development: Accessing Math Game for Children Learning Enhancement. Int. J. Interact. Mob. Technol. 2019, 13, 111. [CrossRef]

50. Yung, O.C.; Junaini, S.N.; Kamal, A.A.; Ibrahim, L. 1 Slash 100\%: Gamification of mathematics with hybrid QR-based card game. Indones. J. Electr. Eng. Comput. Sci. 2020, 20, 1453-1459. [CrossRef]

51. Kalloo, V.; Mohan, P.; Kinshuk, D. A Technique for Mapping Mathematics Content to Game Design. Int. J. Serious Games 2015, 2. [CrossRef]

52. Araya, R.; Jiménez, A.; Bahamondez, M.; Calfucura, P.; Dartnell, P.; Andrade, J.S. Teaching modeling skills using a massively multiplayer online mathematics game. World Wide Web 2012, 17, 213-227. [CrossRef]

53. Main, S.; O’Rourke, J. 'New Directions for Traditional Lessons': Can Handheld Game Consoles Enhance Mental Mathematics Skills? Aust. J. Teach. Educ. 2011, 36, 43-55. [CrossRef]

54. O'Rourke, J.; Main, S.; Hill, S.M. Commercially available Digital Game Technology in the Classroom: Improving Automaticity in Mental-maths in Primary-aged Students. Aust. J. Teach. Educ. 2017, 42. [CrossRef]

55. Shin, N.; Sutherland, L.M.; Norris, C.A.; Soloway, E. Effects of game technology on elementary student learning in mathematics. Br. J. Educ. Technol. 2012, 43, 540-560. [CrossRef]

56. Denham, A.R. Using the PCaRD digital game-based learning model of instruction in the middle school mathematics classroom: A case study. Br. J. Educ. Technol. 2019, 50, 415-427. [CrossRef]

57. Es-Sajjade, A.; Paas, F. Educational theories and computer game design: Lessons from an experiment in elementary mathematics education. Educ. Tech. Res. Dev. 2020, 68, 2685-2703. [CrossRef] 
58. Katmada, A.; Mavridis, A.; Tsiatsos, T. Implementing a Game for Supporting Learning in Mathematics. Electron. J. Elearn. 2014, $12,230-242$.

59. Chiu, F.Y.; Hsieh, M.L. Role-Playing Game Based Assessment to Fractional Concept in Second Grade Mathematics. Eurasia J. Math. Sci. Technol. Educ. 2017, 13, 1075-1083. [CrossRef]

60. Fouze, A.Q.; Amit, M. Development of mathematical thinking through integration of ethnomathematic folklore game in math instruction. Eurasia J. Math. Sci. Technol. Educ. 2018, 14, 617-630. [CrossRef]

61. Dele-Ajayi, O.; Strachan, R.; Pickard, A.J.; Sanderson, J.J. Games for Teaching Mathematics in Nigeria: What Happens to Pupils Engagement and Traditional Classroom Dynamics? IEEE Access 2019, 7, 53248-53261. [CrossRef]

62. Drigas, A.; Pappas, M. On Line and Other Game-Based Learning for Mathematics. Int. J. Online Eng. 2015, 11, 62-67. [CrossRef]

63. Hernàndez, A.; Joanpere, M.; Gorgorió, N.; Albarracín, L. Mathematics learning opportunities when playing a Tower Defense Game. Int. J. Serious Games. 2015, 2, 2384-8766. [CrossRef]

64. Nygren, E.; Blignaut, S.; Leendertz, V.; Sutinen, E. Quantitizing Affective Data as Project Evaluation on the Use of a Mathematics Mobile Game and Intelligent Tutoring System. Inform. Educ. 2019, 18, 375-402. [CrossRef]

65. Gulz, A.; Londos, L.; Haake, M. Preschoolers' Understanding of a Teachable Agent-Based Game in Early Mathematics as Reflected in their Gaze Behaviors-An Experimental Study. Int. J. Artif. Intell. Educ. 2020, 30, 38-73. [CrossRef]

66. Hussain, S.Y.S.; Tan, W.H.; Idris, M.Z. Digital Game-Based Learning for Remedial Mathematics Students: A New Teaching and Learning Approach in Malaysia. Int. J. Multimed. Ubiquitous Eng. 2014, 9, 112-117. [CrossRef]

67. Fellnhofer, K. All-in-One: Impact study of an online math game for educational purposes. Int. J. Technol. Enhanc. Learn. 2016, 8, 59-76. [CrossRef]

68. Plass, J.; O'Keefe, P.; Homer, B.; Case, J.; Hayward, E.; Stein, M.; Perlin, K. The Impact of Individual, Competitive, and Collaborative Mathematics Game Play on Learning, Performance, and Motivation. J. Educ. Psychol. 2013, 105, 1050-1066. [CrossRef]

69. Yang, K.; Chu, H.; Chiang, L. Effects of a Progressive Prompting-based Educational Game on Second Graders' Mathematics Learning Performance and Behavioral Patterns. J. Educ. Technol. Soc. 2018, 21, 322-334.

70. Stebler, R.; Vogt, F.; Wolf, I.; Hauser, B.; Rechsteiner, K. Play-Based Mathematics in Kindergarten. A Video Analysis of Children's Mathematical Behaviour While Playing a Board Game in Small Groups. J. Math. Didakt. 2013, 34, 149-175. [CrossRef]

71. Hung, C.M.; Huang, I.; Hwang, G.J. Effects of digital game-based learning on students' self-efficacy, motivation, anxiety, and achievements in learning mathematics. J. Comput. Educ. 2014, 1, 151-166. [CrossRef]

72. Doğan, Z.; Sönmez, D. The Effect of Using Mathematical Games on Primary School 4th Grade Students' Attitudes towards Mathematics Course and Their Visual Metaphorical Perceptions. J. Educ. E-Learn. Res. 2019, 6, 52-60. [CrossRef]

73. Chen, Z.H.; Liao, C.Y.; Cheng, H.; Yeh, C.; Chan, T.W. Influence of Game Quests on Pupils Enjoyment and Goal-pursuing in Math Learning. J. Educ. Technol. Soc. 2012, 15, 317-327.

74. Kaune, C.; Nowinska, E.; Paetau, A.; Griep, M. Games for Enhancing Sustainability of Year 7 Maths Classes in Indonesia: Theory-Driven Development, Testing and Analyses of Lessons, and of Students Outcomes. J. Math. Educ. 2013, 4. [CrossRef]

75. Bragg, L. Students' conflicting attitudes towards games as a vehicle for learning mathematics: A methodological dilemma. Math. Ed. Res. J. 2007, 19, 29-44. [CrossRef]

76. Barreto, D.; Vasconcelos, L.; Orey, M. Motivation and learning engagement through playing math video games. Malays. J. Learn. Instr. 2017, 14, 1-21. [CrossRef]

77. Veloo, A.; Md-Ali, R.; Chairany, S. Using Cooperative Teams-Game-Tournament in 11 Religious School to Improve Mathematics Understanding and Communication. Malays. J. Learn. Instr. 2016, 13, 97-123. [CrossRef]

78. Calleros, C.B.; Guerrero-García, J.; Navarro-Rangel, Y. UvaMate: A Serious Game for Learning Mathematics for Children with ADHD: Usability Evaluation. Rev. Colomb. Comput. 2020. [CrossRef]

79. Allen, L.E.; Jackson, G.; Ross, J.; White, S. What Counts Is How the Game Is Scored: One Way to Increase Achievement in Learning Mathematics. Simul. Gaming 1978, 9, 371-392.

80. Trujillo, K.; Chamberlin, B.; Wiburg, K.; Armstrong, A. Measurement in Learning Games Evolution: Review of Methodologies Used in Determining Effectiveness of Math Snacks Games and Animations. Technol. Knowl. Learn. 2016, 21, 155-174. [CrossRef]

81. Hieftje, K.; Pendergrass, T.; Kyriakides, T.; Gilliam, W.; Fiellin, L. An Evaluation of an Educational Video Game on Mathematics Achievement in First Grade Students. Technologies 2017, 5, 30. [CrossRef]

82. Pratiwi; Sri, L.; Thompson, J. Simulation and Games Based Learning Model for Learning Math in Higher Education. Univers. J. Educ. Res. 2020, 8, 16-20. [CrossRef]

83. Husman, J.; Derryberry, W.P.; Crowson, H.M.; Lomax, R. Instrumentality, task value, and intrinsic motivation: Making sense of their independent interdependence. Contemp. Educ. Psychol. 2004, 29, 63-76. [CrossRef] 